\title{
On Two Species of Kallymenia (Rhodophyta: Gigartinales: Kallymeniaceae) from the Hawaiian Islands, Central Pacific ${ }^{1}$
}

\author{
Isabella A. Abbott ${ }^{2}$ and Karla 7. McDermid ${ }^{3}$
}

\begin{abstract}
Two species of Kallymenia from the Hawaiian Islands, one rare, $K$. sessilis Okamura, and the other described here for the first time, $K$. thompsonii, n. sp., are examined, compared, and contrasted with other similar Kallymenia species. Both species are unusual because Kallymenia is generally regarded as a temperate taxon, and tropical or subtropical species are seldom encountered. The two species are alike in that they have a female reproductive apparatus that is monocarpogonial: wherein a single carpogonial filament is associated with a supporting cell also bearing an arrangement of subsidiary cells that is characteristic of some of the family Kallymeniaceae. In the genus Kallymenia, vegetative components shown in a cross section are a narrow outer cortex, often only three cells thick, followed inwardly by one to two layers of subcortical cells. In the two species studied here, there appears to be a constant shape and arrangement of subcortical cells in each species, whereas the number of medullary filaments and their arrangements appear to be less stable in their configuration than the subcortical cells. Branched refractive cells or stellate cells, which often occur in species of Kallymenia, were not seen in $K$. thompsonii and only rarely in $K$. sessilis. Kallymenia thompsonii commonly has perforations in the maturing blades, whereas $K$. sessilis does not.
\end{abstract}

Kallymenia sessilis Окамиra, from central Japan, was included in the Hawaiian marine flora recently with a minimum of information because it was not known what the Japanese species looked like beyond its first description. A welcome opportunity was provided when a new species of Kallymenia was collected from Midway Atoll in the Northwestern Hawaiian Islands (NWHI), offering material that could be compared in detail with $K$. sessilis. The two species of Kallymenia reported in this paper occur in relatively deep

\footnotetext{
1 Manuscript accepted 15 August 2001.

${ }^{2}$ Correspondence: Department of Botany, University of Hawai'i at Mānoa, 3190 Maile Way, Honolulu, Hawai'i 96822 (telephone, 808-956-8073; fax, 808-9563923; E-mail, iabbott@hawaii.edu).

${ }^{3}$ Reprint requests: Marine Science Department, University of Hawai'i at Hilo, 200 West Kawili Street, Hilo, Hawai'i 96720 (telephone, 808-933-3906; fax 808974-7693; E-mail, mcdermid@hawaii.edu).
}

Pacific Science (2002), vol. 56, no. 2:149-162 (C) 2002 by University of Hawai'i Press.

All rights reserved
(6 to $10 \mathrm{~m}$ ) to deeper (12 to $20 \mathrm{~m}$ ) water depths. One of them, Kallymenia sessilis Okamura, 1934, was first reported from the Gulf of Tateyama, central Japan, and remains a rare plant in Japan (T. Yoshida, 1999, pers. comm.). It was described and illustrated by Okamura (1934:20-21, pl. 312, figs. 1-5) and was reported from the NWHI and in the main (southeastern) Hawaiian Islands by $\mathrm{Ab}$ bott (1999). The second species, Kallymenia tbompsonii Abbott \& McDermid, n. sp., is described here.

The majority of marine algae previously reported from the NWHI, formerly known as the Leeward Hawaiian Islands, are from intertidal to snorkel depths (about $5 \mathrm{~m}$ ) (Abbott 1989), but in recent years, dredging activities and scuba have made algae from greater depths available for study. Such current collections are obtained from depths of 10 to $100 \mathrm{~m}$ and have brought to light rare new records of species in the Hawaiian Islands (Abbott 1999), such as Crouania mageshimensis Itono, Lejolisea pacifica Itono (both Ceramiaceae), and Kallymenia sessilis Okamura from Japan, and Malaconema minimum Hol- 


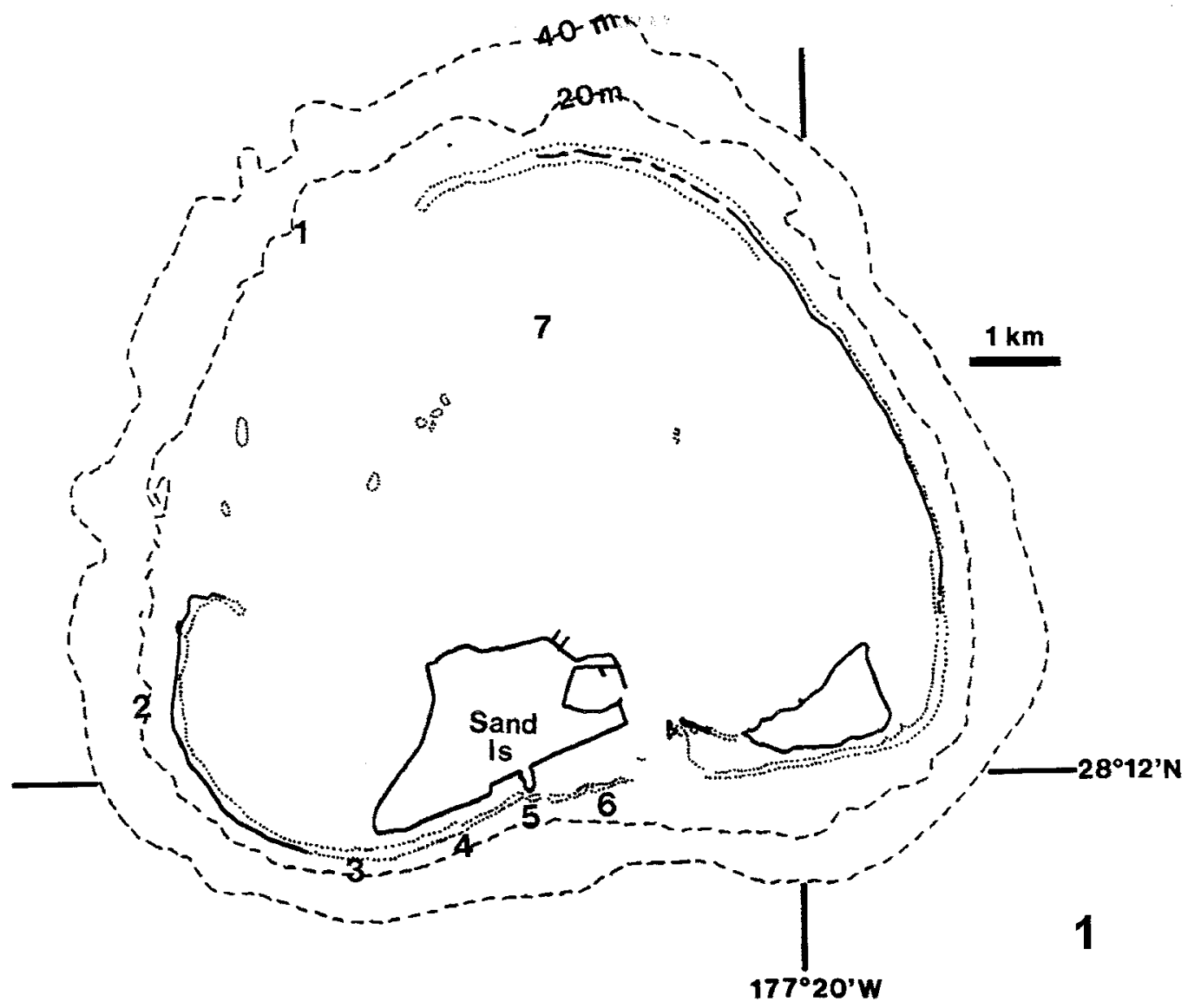

FIGURE 1. Map of Midway Atoll, Northwestern Hawaiian Islands. Collection sites of Kallymenia thompsonii are numbered: 1, Northwest Pass; 2, reef slope off Well's Harbor; 3, reef slope off Frigate Point; 4, reef slope between Frigate Point and "Bulky Dump"; 5, south reef slope ("Mick's Fifty"); 6, Fish Hole; 7, patch reef in north lagoon.

lenberg (Delesseriaceae) from the Marshall Islands, as well as undescribed species such as Dudresnaya babbittiana Abbott \& McDermid (2001) from Midway, and Kallymenia thompsonii, n. sp., discussed in this paper.

The NWHI consist of ten major emergent islands and atolls, plus numerous shoals, pinnacles, seamounts, and reefs, of which Midway Atoll $\left(28^{\circ} 15^{\prime} \mathrm{N}, 177^{\circ} 20^{\prime} \mathrm{W}\right)$ (Figure 1) is historically, as well as phycologically, the best known. Of 205 species of marine algae reported from the entire NWHI in 1989 by Abbott, 102 were from Midway alone. The atoll consists of three small islets in a lagoon 8 $\mathrm{km}$ in maximum diameter. Midway Atoll is the second most northeastern of the NWHI and was established as a National Wildlife Refuge in 1996. The U.S. Fish and Wildlife Service of the U.S. Department of the Interior is responsible for the maintenance of the atoll and has initiated a variety of studies, of which this is one, that documents the natural history of the atoll.

\section{MATERIALS AND METHODS}

Plants of Kallymenia thompsonii, n. sp., were collected using scuba at various sites inside and outside the lagoon at Midway Atoll from 1996 to 2001 (Figure 1). Plants were pressed 
as herbarium specimens and a few portions were preserved in $5 \%$ formalin and seawater. Specimens were later sectioned and prepared for examination following the methods outlined by Tsuda and Abbott (1985), using $0.75 \%$ aniline blue, intensified with a drop of $1 \% \mathrm{HCl}$. Slides were mounted in a $35 \%$ glucose syrup. The type specimen will be deposited in the Herbarium of the Bishop Museum (BISH) in Honolulu (as BISH 654689), with duplicates distributed to the U.S. National Herbarium, Smithsonian Institution (Us), and the University of California, Berkeley (Uc). Microscope slides will be retained at вISH. Herbarium specimens of $K$. sessilis collected on Blonde Reef, Hilo Bay, Hawaici, were sectioned and examined microscopically. Japanese specimens of $K$. sessilis loaned from the Okamura herbarium were also examined.

\section{RESULTS}

Kallymenia thompsonii Abbott \& McDermid, n. $\mathrm{sp}$.

Figures 2-11

LATIN diagnosis: Plantae foliosae, paginis lubricis ubi vivae, compositae ex rosulis 2-3 stratorum laminarum communi haptero centrali. Lamina basalis grandissima et expansa ad $10(-18) \mathrm{cm}$ diam.; laminae superae rosulae parviores, plus irregulares in circumferentia et diametro; lamina basalis ad substratum affixa per discum incrassatum vel crassitudes ventrales hic illic. Laminae atroroseae ad vinaceras; ubi maturae et reproducti, laminas secundarias, ut pote laminulas secus margines distales edentes, vel marginibus erosis laceratisque librisque; aliter laminae marginibus non profunde crenatis vel late dentatis. Paginae laminarum aliquando foraminis amplitudine variabilia. In sectione transversa, laminae $140-250 \mu \mathrm{m}$ latae, 2-3 stratis valde pigmentosarum cellularum corticalium, et 2-3 stratis grandium, irregulatim ovalium vel plerumque trapezialium cellularum subcorticalium. Omnis cellula subcorticalis ad 36 fila medullosa conjuncta. Cellulae externi corticis minutae, ovalis, minus quam $4 \mu \mathrm{m}$ diam., cellulae ferenti circa $5 \mu \mathrm{m}$ lata longaque et parum irregulari in forma. Medulla centralis partem majorem sectionis formans, filis periclinatis et anticlinatis ad cellulas subcorticales et inter se trans medullam connexis; fila 3-13 $\mu \mathrm{m}$ lata, conspicuis plastis taeniformibus. Plantae cystocarpiferae numerosis filis periclinatis et parum paucioribus filis anticlinatis, autem plantae terasporangiferae filis anticlinatis periclinatisque similaribus numeris. Nec stellatae nec giganto-refractivae cellulae observatae. Gametophyta et tetrasporophyta isomorpha. Tetrasporangia in cortice aggregata, numerosa; ubi matura, cruciatim divisa, 13-20 $\mu \mathrm{m}$ lata, 18-22 $\mu \mathrm{m}$ longa. Spermatangia non visa. Procarpia monocarpogonialia, uno filo carpogoniali inter 6 vel plus cellulas subsidiarias. Cystocarpia oculo nudo visibilia, circa $160-200 \mu \mathrm{m}$ diametro, pustulas parvas manifestis carpostomatibus in pagina laminae formantes. Carposporangia sphaerica aspectu polari, $13-20 \mu \mathrm{m}$ aspecti laterali. Fere omnes cellulae gonimoblasti in carposporangia transformantes, cellulis sterilis intermixtis.

english translation: Plants leafy, with slippery surfaces when fresh, consisting of rosettes of 2-3 layers of blades with a common central holdfast. The lower blade the largest and expanded, up to 10 (in one specimen 18$) \mathrm{cm}$ in diameter; the upper blades of the rosette smaller, more irregular in both circumference and diameter; the lowest blade attached to the substratum by a thickened disk or by ventral thickenings here and there. Blades dark rose to wine red; when mature and reproductive, putting forth secondary blades along the distal margins as bladelets, or with eroded and torn and free margins; otherwise blades with shallowly scalloped or broadly dentate margins. Surfaces of blades sometimes with variously sized perforations. In cross section, blades 140-250 $\mu \mathrm{m}$ wide, with 2 , rarely 3 , layers of strongly pigmented cortical cells, and 2-3 layers of large irregularly oval or commonly trapezoidal subcortical cells. Each subcortical cell connected to 3-6 medullary filaments. Outer cortical cells tiny, oval, less than $4 \mu \mathrm{m}$ in diameter, with their bearing cell about $5 \mu \mathrm{m}$ wide by $5 \mu \mathrm{m}$ long and slightly irregular in shape. The central medulla forming the major part of the cross section, with periclinal and anticlinal 


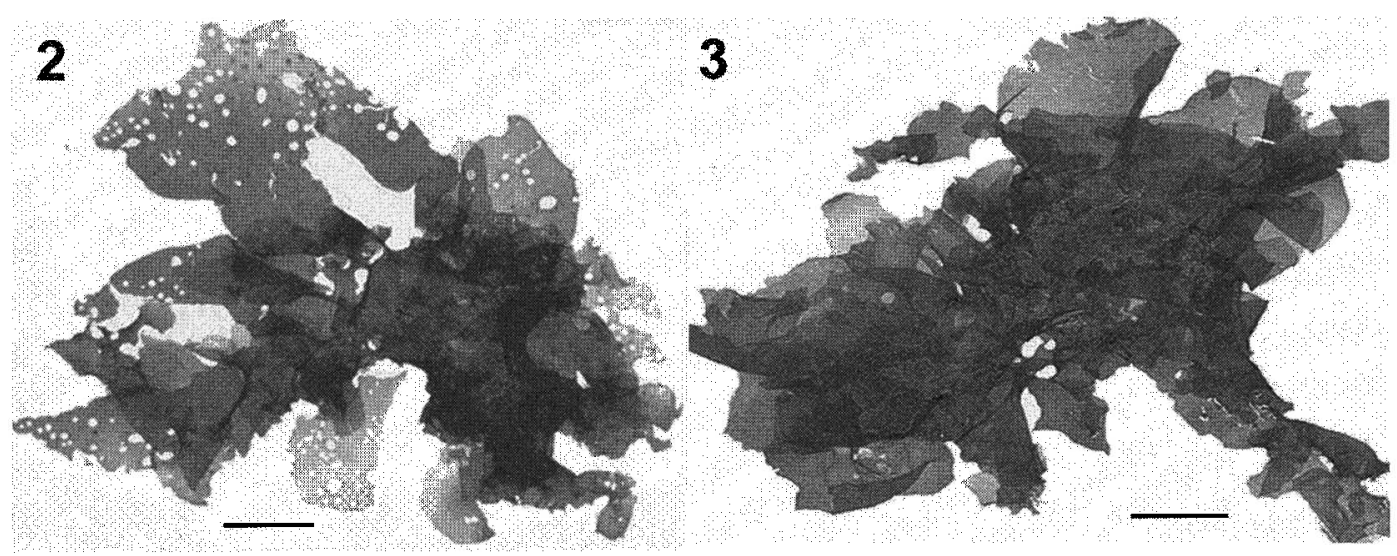

Figures 2-3. Kallymenia thompsonii Abbott \& McDermid. (2) Holotype, KM 4025a (віsн 654689), with cystocarps seen among holes in the thallus at upper left, and dark patch seen at the middle right indicating several layers of blades lying on each other, originating from a central region. The holes are not present in young and developing blades. Scale $=1.5 \mathrm{~cm}$. (3) Paratype (KM 4025b) collected at the same place and date by the same collector as the holotype. Tetrasporangial. Scale $=1.5 \mathrm{~cm}$.

filaments connected to subcortical cells and to each other across the medulla; filaments 3-13 $\mu \mathrm{m}$ wide, with conspicuous ribbonlike plastids. Cystocarpic plants with numerous periclinal filaments and slightly fewer anticlinal filaments, whereas tetrasporangial plants with similar numbers of anticlinal and periclinal filaments. Neither stellate nor giant refractive cells observed. Gametophytes and tetrasporophytes isomorphic. Tetrasporangia numerous, aggregated in the cortex; when mature, cruciately divided, 13-20 $\mu \mathrm{m}$ wide and 18-22 $\mu \mathrm{m}$ long. Spermatangia were not seen. Procarps monocarpogonial, with a single carpogonial filament among 6 or more subsidiary cells. Cystocarps visible with the unaided eye, about $160-200 \mu \mathrm{m}$ in diameter, forming small pustules with obvious carpostomes on the blade's surface. Carposporangia spherical in polar view, $13-20 \mu \mathrm{m}$ in lateral view. Nearly all gominoblast cells becoming carposporangia, intermixed with sterile cells.

TYPE MATERIAL: Holotype: KM 4025a (cystocarpic) (BISH 654689); paratype: KM $4025 \mathrm{~b}$ (tetrasporangial) (в вSH, Us).

TYPE LOCALITY: At 12-19 $\mathrm{m}$ depths, Northwest Pass, Midway Atoll, collected by Karla J. McDermid, 19 September 1996, on coral rubble.
OTHER SPECIMENS EXAMINED: Collected at Midway Atoll (see Figure 1) by Karla J. McDermid, 28 June 1997, 13.5 to $20 \mathrm{~m}$ depths off Frigate Point, KM 4341; 2 August 1997, $20 \mathrm{~m}$ depth between Frigate Point and "Bulky Dump," KM 4372; 2 August 1997, 20 $m$ depth in Well's Harbor, KM 4383; 14 June $1999,3-5 \mathrm{~m}$ depth in crevices of patch reef in north lagoon, KM 4673; 17 June 1999, 12 m deep at Fish Hole, KM 4697; 17 June 1999, $12 \mathrm{~m}$ deep on south reef slope at "Mick's Fifty," KM 4698; 18 May 2001, 14 m deep at Fish Hole, IA 28447.

ETYMology: Named for Mark Thompson, whose vision for the opening of Midway Atoll for controlled ecotourism has made it possible for many to explore and appreciate the exciting natural resources of the Midway Atoll National Wildlife Refuge.

VEgetative STRUCTURES: Plants are erect, in isolated clumps as rosettes composed of 2-3 tiers of blades (Figures 2,3), a wine red, the largest blades $10(-18) \mathrm{cm}$ in width below, with smaller-sized blades above, fastened ventrally by thickened portions of blades or a discoid holdfast. As the plants mature, the margins become torn and eroded in places so that the remaining outer blades (Figure 2) appear to be stipitate from the tat- 
tered margin proximally. The lower blades are undulate along their circumferences and when dried appear folded upon themselves (Figure 3). Perforations sometimes occur on blades.

In cross sections, the blades show a twolayered (Figure 4) cortex, $13 \mu \mathrm{m}$ tall $(n=20$; range, $12.5-13.5 \mu \mathrm{m})$, in which the tiny outer cortical cells are only $3-4 \mu \mathrm{m}$ when measured in the cross section or measured superficially. When examined from the surface, they appear to be paired above their bearing cells, never occurring in triplets. The inner subcortical cells (Figures 4-6, sub) are five or more times larger than the distally adjacent bearing cells of the outer cortex, and in this species inner subcortical cells are mostly trapezoidal (Figures 5, 6), although some cylindrical or rounded cells occur toward the central medulla (Figure 4) from which medullary filaments and individual cells are formed. The subcortical cells may be connected to one to several irregular layers of medullary filaments (Figure 6) that cross the medulla and are especially conspicuous in sections of the blade margins where the medullary filaments appear to have as many as 4-6 pit-connections with these large cells that have thickened walls (Figure 5). Irregularly shaped elongate cells with arms and highly refractive contents are not seen in this species, nor are stellate cells, which are generally star-shaped with pulled-out angular connections either to other similar cells or to filaments.

ReProductive structures: Tetrasporangia form small, rounded patches over the thallus (Figure 7). The tetrasporangia are nearly spherical and are slightly longer than broad. No spermatangia were observed. Carpogonial branch apparatuses and cystocarps are present in plants distinct from those that bear tetrasporangia. The carpogonial apparatus has a single 3 -celled carpogonial (monocarpogonial) filament (Figures 8-10) among large, bone-shaped subsidiary cells (Figure 9, sbc). No connecting filaments were seen leaving this group of cells, nor were any subsidiary or associated cells seen with connecting filaments near them, which would be evidence of the transfer of a fertilized nucleus from the carpogonial apparatus to an auxiliary cell. The conspicuous and deeply staining subsidiary cells belonging to the monocarpogonial apparatus were never seen at the base of a developing cystocarp, which would have perhaps indicated fusion of the carpogonium with the adjacent supporting cell.

The mature cystocarp bears many small carposporangia about $10 \mu \mathrm{m}$ in diameter (Figure 11) before release. They are borne among sterile filaments (Figure 11, sf), which is characteristic of taxa in this family. On release, they are somewhat spherical, $13 \mu \mathrm{m}$ in diameter in polar view, and $20 \mu \mathrm{m}$ in lateral view or longer than broad. The cystocarps make minute blisters on the surface; each has a clear carpostome.

\section{Kallymenia sessilis Okamura \\ Kallymenia sessilis Okamura, 1934, Icones of Japanese Algae, 7 (3): 20, pl. 312.}

Algae dark bluish red, or brownish red, forming flat blades in clusters, or singly, or membranous and broad, sometimes filmy, with shallow or deep lobes (Figure 12), attached by thickened portions of lower margins, or by several pegs; blades with entire margins; outer cortex $20 \mu \mathrm{m}$ tall, the tiny outermost cells $2-3 \mu \mathrm{m}$ in diameter, innermost (subcortical) cells 50 to $150 \mu \mathrm{m}$ wide, rounded (Figure 13), attached by elongated pit-connections to similar adjacent cells and to medullary filaments (Figures 14, 15); medullary filaments consisting of cells $8-13 \mu \mathrm{m}$ in diameter, of various lengths, mostly periclinally directed, not thickly dispersed, and relatively short. Refractive cells linear and very rare.

Spermatangia superficial, 2-3 attached on outer cortical cells in patches. Procarps with one carpogonial branch (monocarpogonial) and 5-6 subsidiary cells per supporting cell. Immediate postfertilization events not observed. Cystocarp (Figure 16) 150 to $200 \mu \mathrm{m}$ in diameter, slightly elevating the cortical layers, forming carposporangia amidst sterile filaments that extend beyond the spore mass; in surface view, cystocarps each appearing like small blisters, each with a carpostome. 

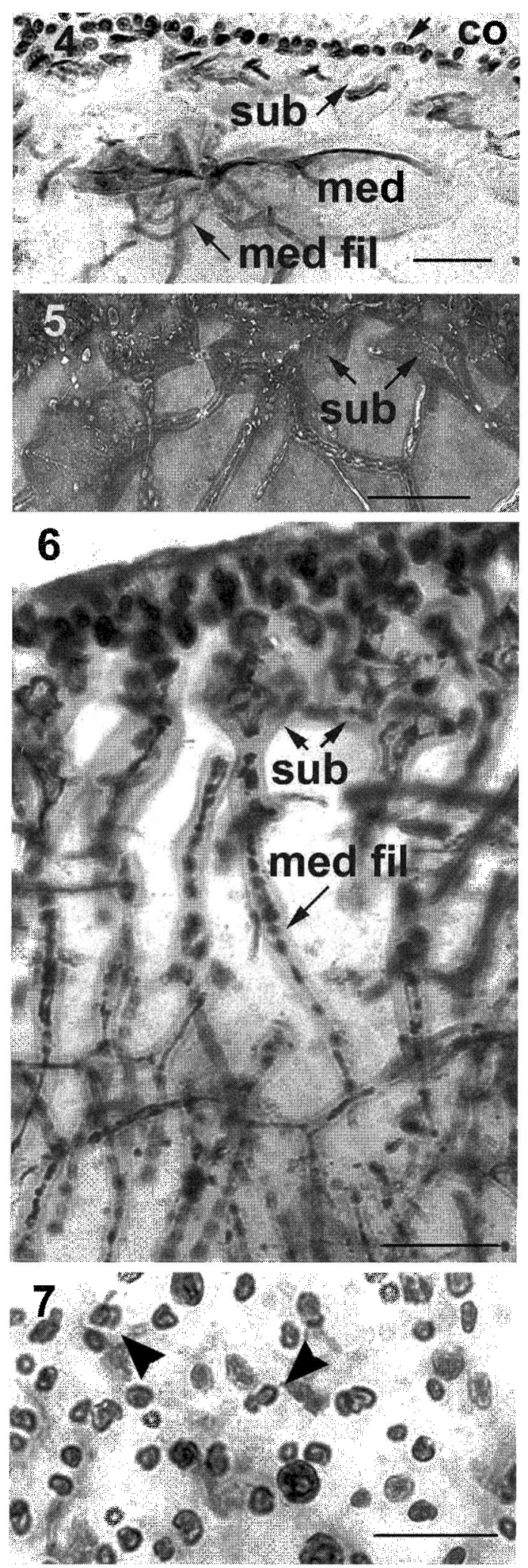

Figures 4-7. Kallymenia thompsonii. (4) Cross section showing two-layered cortex (co) (top arrow) with large subcortical (sub) cells below, and formation of secondary filaments that will become medullary filaments (med fil). The section is from the center of the blade. med, medulla. Scale $=40 \mu \mathrm{m}$. (5) Cross section to show triangular and trapezoidal subcortical cells (sub) attached to medullary filaments. Phase contrast micrograph. Scale $=40 \mu \mathrm{m}$. (6) Oblique to median section showing several layers of squashed cortical cells at top, and trapezoidal subcortical layer (double arrows) beneath a cortex, with medullary filaments (med fil) (single arrow) attached to subcortical cells (sub) and to each other. Scale $=40 \mu \mathrm{m}$. (7) Surface view of scattered tetrasporangia (larger dark objects) among paired cortical cells (arrowheads). Scale $=40 \mu \mathrm{m}$. 

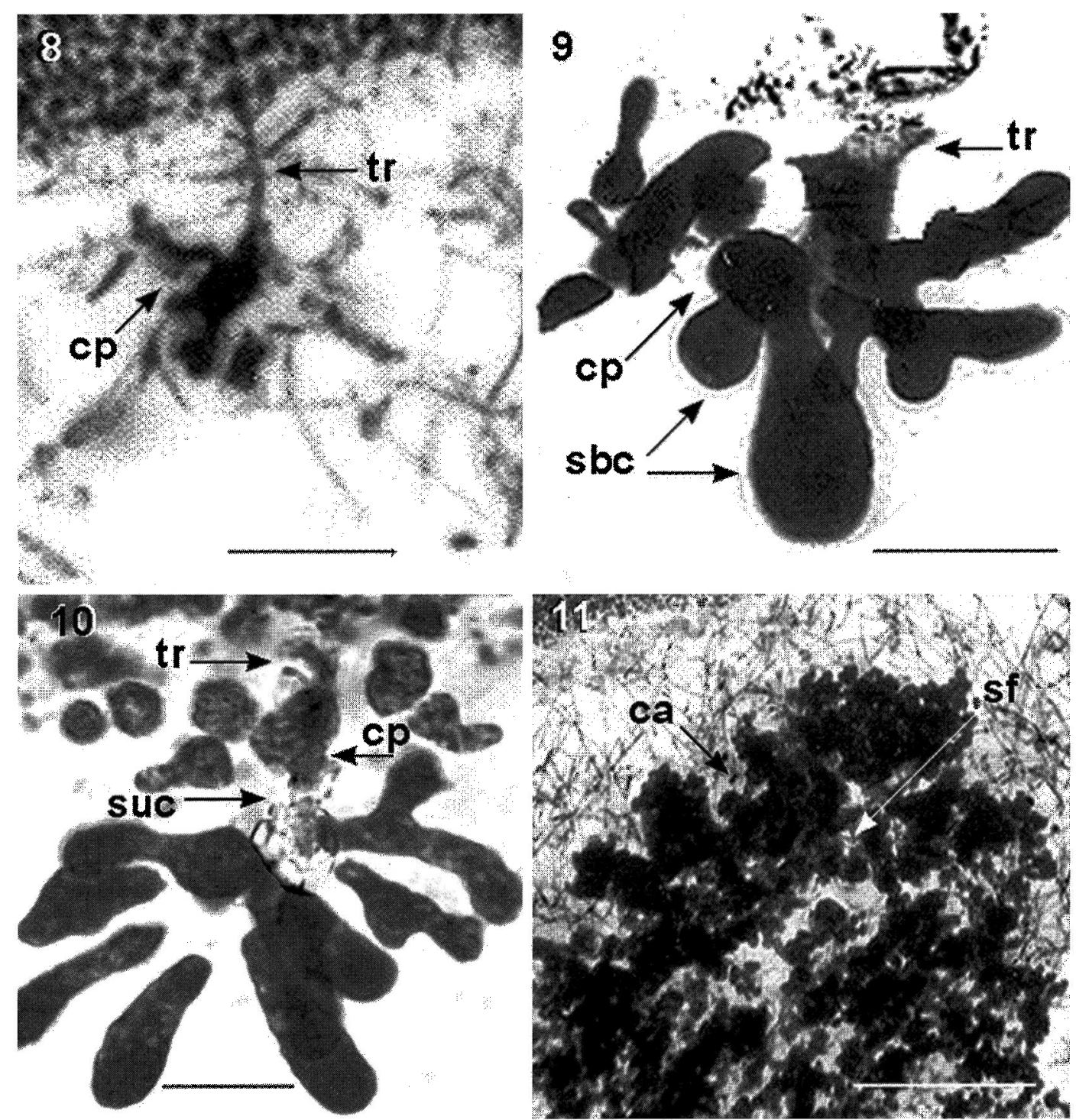

Figures 8-11. Kallymenia thompsonii. (8) Portion of young monocarpogonial arrangement showing parts of young carpogonium (cp) with trichogyne (tr) reaching the cortex. Scale $=40 \mu \mathrm{m}$. (9). Squashed monocarpogonial apparatus, showing trichogyne (tr) at top, part of carpogonial filament ( $\mathrm{cp}$ ) hidden by subsidiary cell, and several lobed subsidiary cells (sbc). Scale $=30 \mu \mathrm{m}$. (10) Squashed subsidiary cells showing relationship to supporting cell (suc), and carpogonium $(\mathrm{cp}$ ) with displaced trichogyne (tr). Scale $=30 \mu \mathrm{m}$. (11) Portion of mature cystocarp with carposporangia (ca) mixed with sterile filaments (sf) in the medulla. Scale $=40 \mu \mathrm{m}$.

Tetrasporangia (Figure 17) are in scattered patches in the cortex, nearly spherical to slightly elongated, $18-26 \mu \mathrm{m}$ in diameter by 26-39 $\mu \mathrm{m}$ long.
Distribution: Gulf of Tateyama, central Japan (type locality); Hawaiian Islands from Kure Atoll, French Frigate Shoals, and Nihoa Island (NWHI), and Kaua'i, O'ahu, Maui, 


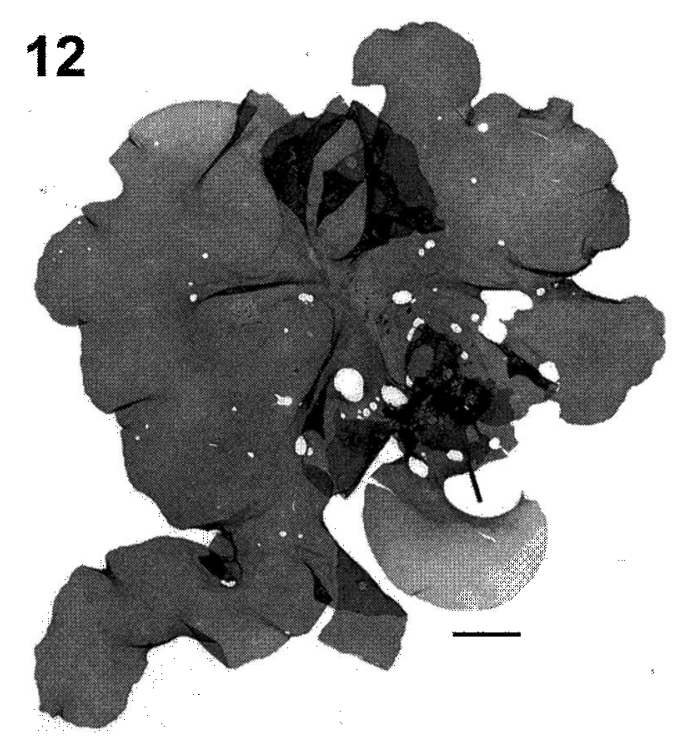

FIGURE 12. Hawaiian specimen of Kallymenia sessilis (KM 5050), a species from Japan, showing broadly rounded lobes, no layers of blades, and thicker blades than the thallus of $K$. thompsonii, collected at Blonde Reef, Hilo, Hawai'i Island, $6.5 \mathrm{~m}$ depth, 18 August 1995. Scale $=3 \mathrm{~cm}$.

and Hawaici Islands among the main southeastern Hawaiian Islands. All collections were made at depths of 1 to $10 \mathrm{~m}$, often growing among living coral.

This description is largely based upon that of Abbott (1999), with additional information from specimens that were collected subsequently and not included in that publication. The greatest similarity between this description and that of Okamura (1934) is in the shapes of the thick-walled, rounded subcortical cells (Figures 13-14 in this paper and Okamura's pl. 312, nos. 3, 4). Indeed, in many sections of the type specimen of Kallymenia sessilis from the Okamura herbarium (SAP), the only feature found that could usefully be compared with the more recently collected Hawaiian material was the round, thick-walled cells. The Japanese material had cell walls that had polymerized so much from age that they shattered, rather than yielding to a sharp razor blade, and the material "gelatinized" completely on application of water or detergent.

The greatest differences are shown in Figure 15 , in which the relationship of the filamentous medullary cells to the subcortical cells is detailed; in Okamura's plate the medullary filaments are not shown at all. In most modern studies of the Kallymeniaceae (e.g., Womersley 1994), the structure of the medulla is shown in most taxa. A further difference is the thickness of the blades of the Japanese specimens, $130-160 \mu \mathrm{m}$, compared with $350-400 \mu \mathrm{m}$ widths in the Hawaiian plants.

Table 1 compares and contrasts various morphological, anatomical, and reproductive characteristics of several Kallymenia species. The Hawaiian species, $K$. sessilis and $K$ thompsonii, are juxtaposed with other Pacific Basin and one South African species that share similar general foliose blade morphology, including the presence of perforations. These species were also chosen for comparison because reproductive material has been described and well illustrated. This collection of taxa immediately can be divided into two groups: species with polycarpogonial carpogonial branch systems ( $K$. cribrogloea Womersley \& Norris, $K$. papenfussii Norris, $K$. pertusa Setchell \& Gardner, and $K$. rosea Womersley \& Norris), and species with monocarpogonial carpogonial branch systems $(K$. 


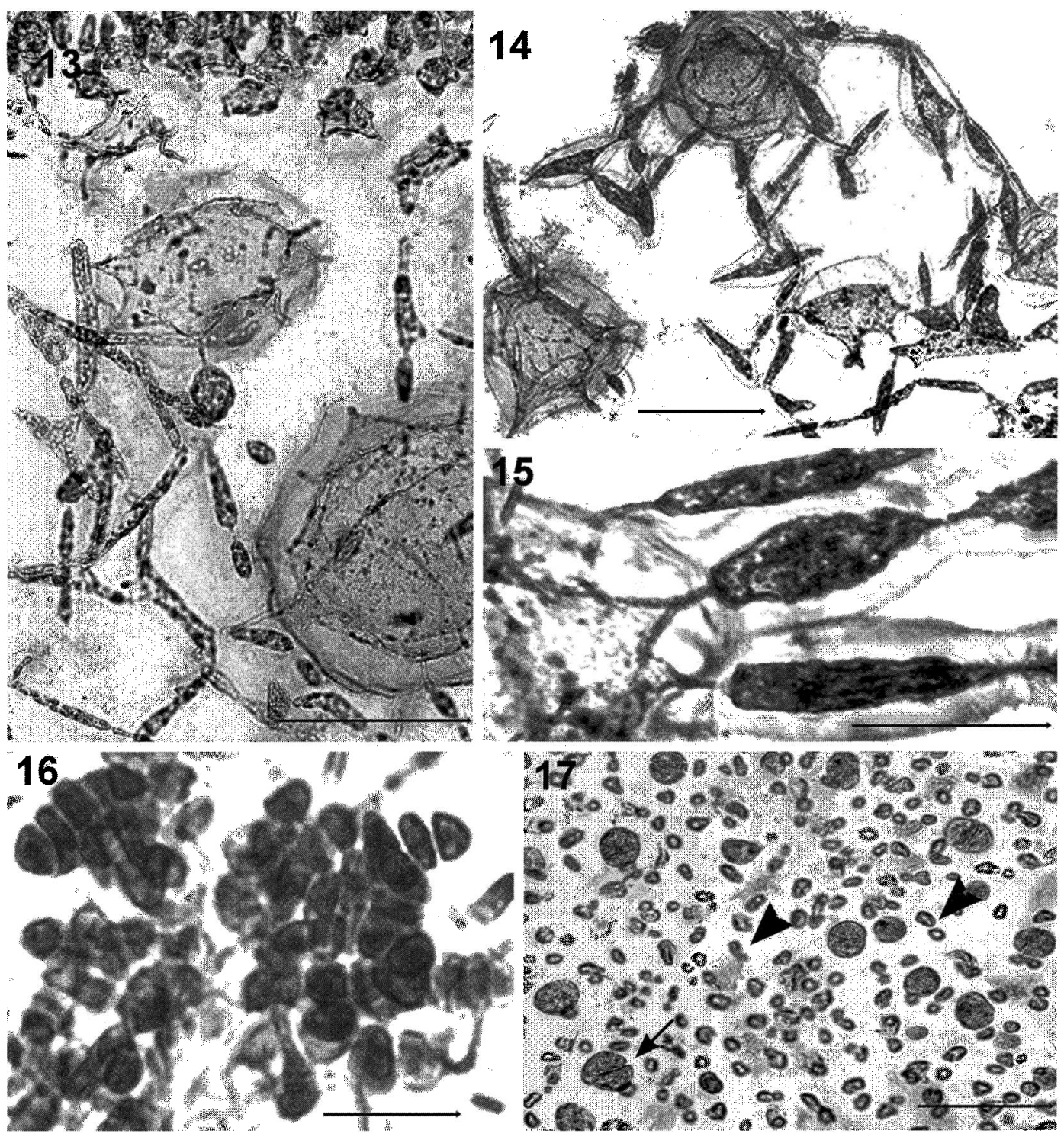

FIgUREs 13-17. Kallymenia sessilis. (13) Squashed, rounded subcortical cells showing attachment of several photosynthetic filament/medullary filaments from each cell. Scale $=50 \mu \mathrm{m}$. (14) Detail of arrangement of several medullary filaments and their connections to subcortical cells, and the thickness of the walls. Scale $=50 \mu \mathrm{m}$. (15) Three elongated, darkly stained medullary cells in the middle of the picture show protoplasmic ("pit") connections from the subcortical cell on the left to other medullary cells on the right, an indication that the medulla is filamentous. Scale $=70 \mu \mathrm{m}$. (16) Developing carposporangia within a cystocarp. Scale $=20 \mu \mathrm{m}$. (17) Superficial view of a tetrasporangial patch with arrowheads showing paired tops of cortical cells. Arrow points to a tetrasporangium that has divided. Scale $=40 \mu \mathrm{m}$. 
TABLE 1

Comparison of Perforate Kallymenia Species with K. sessilis and K. thompsonii from Hawai' $\mathrm{i}$

\begin{tabular}{|c|c|c|c|c|c|c|c|c|}
\hline Parameter & $K$ cribrogloea $a^{a}$ & K. cribrosa $a^{a}$ & $K$. papenfussi $i^{b}$ & $K$ perforatac & $K$. pertusa $a^{d}$ & $K$. rasea $^{e}$ & $K$ sessilisf & $K$ tbompsonïg \\
\hline Habit & $\begin{array}{l}\text { Foliose, } \\
\text { undivided or } \\
\text { lobed, } \\
\text { gelatinous, } \\
\text { and firm }\end{array}$ & $\begin{array}{l}\text { Foliose, } \\
\text { undivided, } \\
\text { margins } \\
\text { smooth, } \\
\text { gelatinous, and } \\
\text { firm }\end{array}$ & $\begin{array}{l}\text { Cuneate thallus, } \\
\text { lacinate at } \\
\text { broad end, } \\
\text { thin }\end{array}$ & $\begin{array}{l}\text { Undulato-plaited, } \\
\text { somewhat } \\
\text { umbilicated, } \\
\text { waved, entire } \\
\text { margin, lobed, } \\
\text { strongly } \\
\text { adherent }\end{array}$ & $\begin{array}{l}\text { Irregular } \\
\text { outline, } \\
\text { crenate to } \\
\text { serrate } \\
\text { margin, thin }\end{array}$ & $\begin{array}{l}\text { Foliose, lobed } \\
\text { with leaflets } \\
\text { on surface, } \\
\text { soft, rubbery, } \\
\text { thin }\end{array}$ & $\begin{array}{l}\text { Clusters of large } \\
\text { flat blades, } \\
\text { lobed, entire } \\
\text { margins }\end{array}$ & $\begin{array}{l}\text { Roseftes, tiers of } \\
2-3 \text { blades, } \\
\text { undulate } \\
\text { margins }\end{array}$ \\
\hline Color & $\begin{array}{l}\text { Rose to } \\
\text { brownish red }\end{array}$ & Rose red & Light rose red & $\begin{array}{l}\text { Deep crimson } \\
\text { lake to rose to } \\
\text { dirty red }\end{array}$ & Rose red & Rose red & $\begin{array}{l}\text { Rose red to } \\
\text { brownish red }\end{array}$ & $\begin{array}{l}\text { Dark rose or } \\
\text { wine red }\end{array}$ \\
\hline Attachment & $\begin{array}{l}\text { Short stipe with } \\
\text { discoid } \\
\text { holdfast } 1-3 \\
\text { mm diam. }\end{array}$ & $\begin{array}{l}\text { Subsessile or } \\
\text { short stipe with } \\
\text { holdfast } 1-3 \\
\text { mm }\end{array}$ & $\begin{array}{l}\text { Single stipe and } \\
\text { holdfast }\end{array}$ & $\begin{array}{l}\text { Minute scutate } \\
\text { basal disks or } \\
\text { wherever } \\
\text { touches }\end{array}$ & $\begin{array}{l}\text { Attached to } \\
\text { Sargassum }\end{array}$ & Short stipe & $\begin{array}{l}\text { Thickened } \\
\text { portions, pegs }\end{array}$ & $\begin{array}{l}\text { Disk or } \\
\text { thickened } \\
\text { blade edges }\end{array}$ \\
\hline Thallus size & $50 \times 50 \mathrm{~cm}$ & $30 \times 30 \mathrm{~cm}$ & $18 \times 11 \mathrm{~cm}$ & $\begin{array}{r}30-60 \mathrm{~cm} \times \\
30-60 \mathrm{~cm}\end{array}$ & $\begin{array}{l}5-35 \mathrm{~cm} \\
\text { length } \times \\
14 \mathrm{~cm} \text { wide }\end{array}$ & $30 \times 30 \mathrm{~cm}$ & $\begin{array}{l}\text { 9-18(30) cm } \\
\text { length }\end{array}$ & $\mathrm{Up}_{\mathrm{p}}$ to $10 \mathrm{~cm}$ \\
\hline $\begin{array}{l}\text { Cross section } \\
(\mu \mathrm{m})\end{array}$ & $250-700$ & $200-500(1,000)$ & $\begin{array}{l}122 \text { at margins, } \\
1,143 \text { at base }\end{array}$ & 1,140 & $300-370$ & $\begin{array}{l}\text { Dried } \\
\quad<100(150), \\
\text { fresh } \\
(150) 250-300\end{array}$ & $\begin{array}{l}350-400^{b} \\
130-160^{j}\end{array}$ & $140-250$ \\
\hline $\begin{array}{l}\text { No. of cortex } \\
\text { layers }\end{array}$ & 2 to 4 & 3 to 4 & 1 & 1 to 2 & 2 to 4 & 2 to 3 & $\begin{array}{l}2 \text {, width }= \\
20 \mu \mathrm{m}\end{array}$ & $\begin{array}{l}\text { 2, width }= \\
13 \mu \mathrm{m}\end{array}$ \\
\hline $\begin{array}{l}\text { Outer cortical } \\
\text { cells }(\mu \mathrm{m})\end{array}$ & 5-9(12) angular & (3) $4-6(7)$ rounded & - rounded & - & $\begin{array}{l}\text { 4-6, } \\
\text { palisadelike }\end{array}$ & $\begin{array}{l}5-9, \text { compact, } \\
\text { round to } \\
\text { ovoid }\end{array}$ & $2-3$, ovoid & $3-4$, rounded \\
\hline $\begin{array}{l}\text { Inner cortical } \\
\text { cells }(\mu \mathrm{m})\end{array}$ & Oval to polygon & $\begin{array}{l}\text { Ovoid to polygon } \\
\text { or spherical }\end{array}$ & $\begin{array}{l}\text { Angular, } \\
\text { elongate }\end{array}$ & Roundish & Large angular & $\begin{array}{l}\text { Ovoid, with } \\
\text { large } \\
\text { intercellular } \\
\text { spaces }\end{array}$ & $\begin{array}{l}\text { Rounded-obovate, } \\
52 \times 52 \text { to } 78- \\
92 \times \\
97-115 \text {, inner } \\
\text { wall thickened }\end{array}$ & $\begin{array}{l}\text { Trapezoidal 15- } \\
39 \times 30-80, \\
\text { no thickened } \\
\text { wall }\end{array}$ \\
\hline Stellate cells & $\begin{array}{l}\text { Light staining } \\
50-100 \mu \mathrm{m} \\
\text { with arms } 1- \\
2 \times \text { as long as } \\
\text { cell body }\end{array}$ & $\begin{array}{l}\text { Light staining, } \\
\text { (40)90-160 } \mu \mathrm{m}, \\
\text { arms rarely } \\
\text { longer than cell } \\
\text { body }\end{array}$ & $\begin{array}{l}\text { Yes, deep } \\
\text { staining }\end{array}$ & - & $\begin{array}{l}\text { Yes, filled with } \\
\text { dense } \\
\text { material } 30 \\
\mu \text { m diameter }\end{array}$ & $\begin{array}{l}\text { Light staining, } \\
\text { about } 50 \mu \mathrm{m} \\
\text { diameter }\end{array}$ & $\begin{array}{l}\text { Refractive cells } \\
\text { rare, linear, } \\
5 \times 130 \mu \mathrm{m}\end{array}$ & None observed \\
\hline
\end{tabular}




\begin{tabular}{|c|c|c|c|c|c|c|c|c|}
\hline $\begin{array}{l}\text { Med. filaments } \\
\text { diam. }(\mu \mathrm{m})\end{array}$ & $\begin{array}{l}\text { 4-10(14) often } \\
\text { swollen }\end{array}$ & $(4) 6-10$ & $1-2.5$ & Laxly interwoven & $3-4.0$ & $\begin{array}{l}\text { 3-8, sparse, } \\
\text { loose, coarse }\end{array}$ & $5-10$ & $3-13$ \\
\hline $\begin{array}{l}\text { Carpogonial } \\
\text { branch system }\end{array}$ & Polycarpogonial & Monocarpogonial & Polycarpogonial & Monocarpogonial & Polycarpogonial & Polycarpogonial & Monocarpogonial & Monocarpogonial \\
\hline Auxiliary cell & $\begin{array}{l}8 \text { subsidiary } \\
\text { cells }\end{array}$ & $\begin{array}{l}3-5 \text { subsidiary } \\
\text { cells }\end{array}$ & $\begin{array}{l}5-8 \text { subsidiary } \\
\text { cells }\end{array}$ & $\begin{array}{l}6-11 \text { auxiliary } \\
\text { cells }\end{array}$ & $\begin{array}{l}4 \text { subsidiary } \\
\text { cells }\end{array}$ & $\begin{array}{l}5-9 \text { subsidiary } \\
\text { cells }\end{array}$ & - & - \\
\hline $\begin{array}{l}\text { Carposporangia } \\
(\mu \mathrm{m})\end{array}$ & $\begin{array}{l}\text { Subspherical, } \\
14-30\end{array}$ & $\begin{array}{l}\text { Spherical-ovoid, } \\
\text { (10)14-20 }\end{array}$ & - & Spherical-ovoid & - & - & $10 \times 10$ & $13 \times 20$ \\
\hline $\begin{array}{l}\text { Tetrasporangia } \\
(\mu \mathrm{m})\end{array}$ & $\begin{array}{l}\text { Oroid } 22-36 \times \\
17-25\end{array}$ & $\begin{array}{l}\text { Ovoid, } 20- \\
28 \times 17-19\end{array}$ & 20--22 diameter & - & - & Ovoid, $14 \times 24$ & $18 \times 20$ & $13 \times 20$ \\
\hline Perforations & $\begin{array}{l}\text { Scattered: large } \\
(1-2 \mathrm{~cm}) \text { and } \\
\text { small }(1-2 \\
\mathrm{mm})\end{array}$ & $\begin{array}{l}\text { Scattered evenly: } \\
\text { large }(<5 \mathrm{~mm}) \\
\text { and small } \\
(1-2 \mathrm{~mm})\end{array}$ & $\begin{array}{l}\text { Irregularly } \\
\text { scattered: } \\
\text { circular, } \\
\text { variable sizes }\end{array}$ & $\begin{array}{l}\text { On plants of all } \\
\text { ages, circular to } \\
\text { oblong, up to } 3 \\
\mathrm{~cm}\end{array}$ & $\begin{array}{l}\text { Irregularly } \\
\text { spaced, many, } \\
\text { large, up to } \\
40 \mathrm{~mm}\end{array}$ & Some & $\begin{array}{l}\text { Rare, without } \\
\text { pattern, 1-5 } \\
\text { mm }\end{array}$ & $\begin{array}{l}\text { Common, } \\
\text { irregularly } \\
\text { spaced, } 2-4 \\
\text { mm }\end{array}$ \\
\hline Distribution & $\begin{array}{l}\text { S Australia, } 7- \\
40 \mathrm{~m} \text { deep }\end{array}$ & $\begin{array}{l}W \text { and S Aus- } \\
\text { tralia, 3- } \\
40 \mathrm{~m} \text { deep }\end{array}$ & $S$ Africa in drift & $\begin{array}{l}\text { Japan, Ceylon, } \\
\text { Tropics }\end{array}$ & $\begin{array}{l}\text { Gulf of } \\
\text { Califonia, } \\
\text { Mexico, } 25 \mathrm{~m} \\
\text { deep }\end{array}$ & $\begin{array}{l}\text { Botany Bay, } \\
\text { NSW, } 18 \mathrm{~m} \\
\text { deep }\end{array}$ & $\begin{array}{l}\text { Central Japan, } \\
\text { Hawaiian } \\
\text { Islands, 1-10 m } \\
\text { deep }\end{array}$ & $\begin{array}{l}\text { Midway Atoll, } \\
12-20 \mathrm{~m} \text { deep }\end{array}$ \\
\hline
\end{tabular}

Note: Data in this table are derived from literature references, calculations based on figures and descriptions of non-Hawaiian species, and actual observations of Hawaiian specimens. a Womersley and Norris (1971) and Womersley (1994).

${ }^{b}$ Norris (1964).

C Okamura (1912) and Segawa (1965)

${ }^{d}$ Setchell and Gardner (1924) and Norris and Norris (1973).

${ }^{e}$ Womersley and Norris (1971) and Womersley (1973).

$f$ Okamura (1934), Segawa (1965), and Hawai'i specimens.

$g$ Hawai'i specimens.

${ }^{b}$ Hawaici specimens.

$j$ Japan specimens. 
cribrosa Harvey, $K$. perforata J. Agardh, $K$. sessilis Okamura, and $K$. thompsonii Abbott \& McDermid, n. sp.). The latter four monocarpogonial species are similar in the display of their subsidiary cells in the carpogonial branch system and sporangial measurements (when reported). However, these four monocarpogonial species differ among themselves in shapes and sizes of blades, attachment, blade thickness, inner cortical cell shapes, and in the position of their medullary filaments (periclinal versus anticlinal). The two $\mathrm{Ha}-$ waiian species are similar in that they are monocarpogonial with conspicuous bonelike subsidiary cells, and they have large subcortical cells that contribute to the formation of the medullary filaments directly through numerous secondary pit-connections. However, thanks to abundant material for study, we were able to document that these two species consistently differ in other characteristics as well, including blade habit, size of cross sections, shapes of large subcortical cells, and carposporangial and tetrasporangial sizes. Of the monocarpogonial, foliose, tropical species compared in Table $1, K$. thompsonii is the only one that forms low-growing rosettes, has the smallest blade dimensions, has the thinnest cross section, shows trapezoid-shaped inner cortical cells, lacks refractive cells, and commonly has irregularly scattered small perforations. Blade perforations are rare and randomly positioned in $K$. sessilis (Segawa 1965); large and small perforations are scattered evenly throughout the blades in $K$. cribrosa (Womersley and Norris 1971), and in K. perforata the large holes dominate the blade, creating an Ulva reticulata-like appearance (Okamura 1912, pl. 86) - all very different from $K$. thompsonii.

\section{DISCUSSION}

When faced with the identification of foliose Rhodophyta, several features can be applied generally to various species of Halymenia and Cryptonemia (Halymeniaceae) and shared with species of Kallymenia (Kallymeniaceae), such as attachment, size of the blade, width of the cross section, anticlinal medullary filaments, and the number of cortical layers.
Slender, elongate, highly refractive cells may be found in species of Cryptonemia and Halymenia, as well as other species of Kallymenia (Norris 1957, Chiang 1970), and may be abundant or few in various parts of the same thallus in K. oblongifructa (Setchell) Setchell (Abbott 1968), for example. The anatomy of most Kallymenia species seen in Norris (1964), Womersley and Norris (1971), and Womersley (1994) shares a preponderance of periclinal filaments in the medulla, whereas anticlinal filaments are common in the two Hawaiian Kallymenia species. Anticlinal medullary filaments are also one of the important features of Halymenia. The two Kallymenia species discussed in this paper differ from Halymenia in terms of the sizes and shapes of the inner cortical cells (Kraft and Abbott 1997) (in general smaller in Halymenia, with a few more subcortical layers). More important, members of the genus Kallymenia show a cystocarp in which carposporangia are developed among many sterile filaments, not true of any species of Halymenia or Cryptonemia. Among these three "red blade" genera, only Kallymenia shows the characteristically large subsidiary cells that are the hallmark of Kallymenia and other genera of the Kallymeniaceae. These last two features are therefore pivotal, and are required when identifying species within the genus and the family. We emphasize these reproductive features because the bulk of tropical red, bladelike algae are sterile when examined and not well enough known to identify in that state.

The principal reproductive difference between the two Hawaiian species and the type species of the genus, Kallymenia reniformis (Turner) J. Agardh (1851), as well as some morphologically similar species (see Table 1), is that the Hawaiian species have one carpogonial branch per supporting cell (monocarpogonial); whereas $K$. reniformis (Hommersand \& Ott 1970), K. cribrogloea, K. papenfussii, $K$. pertusa, and $K$. rosea have two or more carpogonial branches per supporting cell (polycarpogonial). The bulk of Kallymenia species and genera in the Kallymeniaceae in Australia (Womersley 1994) in which the carpogonial apparatus is known show the monocarpogonial arrangement associated 
with the supporting cell. Four foliose species that show a monocarpogonial carpogonial branch system and conspicuously lobed or "bone-shaped" subsidiary cells of the carpogonial branch apparatus are now reported from the Indo-Pacific Ocean: Kallymenia cribrosa, $K$. perforata, $K$. sessilis, and $K$. thompsonii. The monocarpogonial condition is thought to be more advanced evolutionarily than the polycarpogonial one (Norris 1957: fig. 22). Assuming that fertilization had taken place, we did not observe a connecting filament leaving the monocarpogonial apparatus and its subsidiary cells, nor did we observe a developing auxiliary cell and its subsidiary cells that might serve as the site of initiation of the gonimoblast. Should these connecting structures not be found, the implication is that in these species of Kallymenia it is possible that this step in development has been eliminated and the supporting cell of the single carpogonial branch is serving as the site of gonimoblast initiation, as postulated by Norris (1957) for Eutbora and Callocolax.

To distinguish species in Kallymenia requires a shift of emphasis to vegetative structure and assessment of enough specimens to understand the variation in the selected features. In a survey of foliose, perforate species of Kallymenia, we found that the sizes and shapes of subcortical (inner cortical) cells varied among these species (Table 1), so that examination of many sections of each might show nearly all types of cells. However, there seemed to be a preponderance of one or another kind in each species. Together with the presence or absence of stellate cells and/or refractive cells, these cellular differences seem to contribute one of several adequate characteristics by which species may be distinguished. At least for the material we have of $K$. sessilis, the large, rounded to obovate cells of the subcortex that lie just below the cortical cells are contrasted with the numerous trapezoidal cells in a similar position in $K$. thompsonii. It is possible that more material, perhaps collected in a different season, may show that these shapes and sizes are not species-specific, but at this time we find them to be fairly constant in both reproductive and sterile specimens. The rounded subcortical cells are found in the same specimens that bear slender, highly refractive, elongate cells among the subcortical cells in $K$. sessilis; these are lacking in $K$ t tbompsonii. In addition, blade perforation frequency, pattern on the blade, and size varied substantially among the species, enough to distinguish $K$. thompsonii from other monocarpogonial species. Finally, $K$. thompsonii with its tiers of blades that form rosettes is distinctive for reported species of Kallymenia.

\section{ACKNOWLEDGMENTS}

We thank the U.S. Fish and Wildlife Service (U.S. Department of the Interior, Pacific Islands Region) for permission to collect marine algae in the Midway National Wildlife Refuge and for boat and diving help. The isolation of Midway Atoll from the main $\mathrm{Ha}-$ waiian Islands made it impossible for us to conduct this research without their interest and help. We acknowledge the help of Teena Michael in photographically interpreting the anatomical intricacies shown by these species. We also thank Professor M. Masuda for the loan of specimens of Kallymenia sessilis from the Okamura herbarium. We greatly appreciate the help of the referees, particularly Max Hommersand, for suggestions that helped to expand the interpretations of our observations.

\section{Literature Cited}

Abbott, I. A. 1968. Studies in some foliose red algae of the Pacific coast: III. Dumontiaceae, Weeksiaceae, Kallymeniaceae. J. Phycol. 4:180-198, 38 figs.

. 1989. Marine algae of the Northwest Hawaiian Islands. Pac. Sci. 43:223-233.

. 1999. Marine red algae of the Hawaiian Islands. Bishop Museum Press, Honolulu, Hawai'i.

Abbott, I. A., and K. J. McDermid. 2001. Dudresnaya babbittiana (Dumontiaceae, Gigartinales), a new red algal species from Midway Atoll, North Central Pacific. Cryptogam. Algol. 22:249-261. 
Agardh, J. G. 1851. Species, genera et ordines algarum. 2: Algas florideas complectens. Pt. 1. Lund.

Chiang, Y. M. 1970. Morphological studies of red algae of the family Cryptonemiaceae. Univ. Calif. Publ. Bot. 58:1-92, 10 pls.

Hommersand, M. H., and D. W. Ott. 1970. Development of the carposporophyte of Kallymenia reniformis (Turner) J. Agardh. J. Phycol. 6:322-331.

Kraft, G. T., and I. A. Abbott. 1997. Platoma ardreanum (Schizymeniaceae, Gigartinales) and Halymenia chiangiana (Halymeniaceae, Halymeniales), two new species of proliferous, foliose red algae from the Hawaiian Islands. Cryptogam. Algol. 18:97-116, 27 figs.

Norris, R. E. 1957. Morphological studies on the Kallymeniaceae. Univ. Calif. Publ. Bot. 28:251-334, pls. 28-40.

- 1964. The morphology and taxonomy of South African Kallymeniaceae. Bot. Mar. 7:90-129.

Norris, R. E., and J. N. Norris. 1973. Kallymenia pertusa (Rhodophyceae, Cryptonemiales) from the Gulf of California. Phycologia 12 (1/2): 71-74.

Okamura, K. 1912. Icones of Japanese algae. Vol. 2, pt. 8, pp. 127-141, pls. 86-90. Tokyo.
1934. Icones of Japanese algae. Vol. 7, pp. 19-48 (English), 17-43 (Japanese), pls. 311-325. Tokyo.

Segawa, S. 1965. Coloured illustrations of the seaweeds of Japan. Rev. ed. Hoikusha, Osaka.

Setchell, W. A., and N. L. Gardner. 1924. Expedition of the California Academy of Sciences to the Gulf of California in 1921. The marine algae. Proc. Calif. Acad. Sci., 4th series, 12:695-949, pls. 12-28, map.

Tsuda, R. T., and I. A. Abbott. 1985. Collection, handling, preservation, and logistics. Pages 67-86 in M. M. Littler and D. S. Littler, eds. Handbook of phycological methods: Ecological methods for macroalgae. Cambridge University Press, New York.

Womersley, H. B. S. 1973. Further studies on Australian Kallymeniaceae (Rhodophyta). Trans. R. Soc. S. Aust. 97:253-256.

1994. The marine benthic flora of Southern Australia, Rhodophyta. Part IIIA. Flora of Australia Supplementary Series No. 1. Australian Biological Resources Study, Canberra.

Womersley, H. B. S., and R. E. Norris. 1971. The morphology and taxonomy of Australian Kallymeniaceae (Rhodophyta). Aust. J. Bot. Suppl. Ser. 2:1-62. 